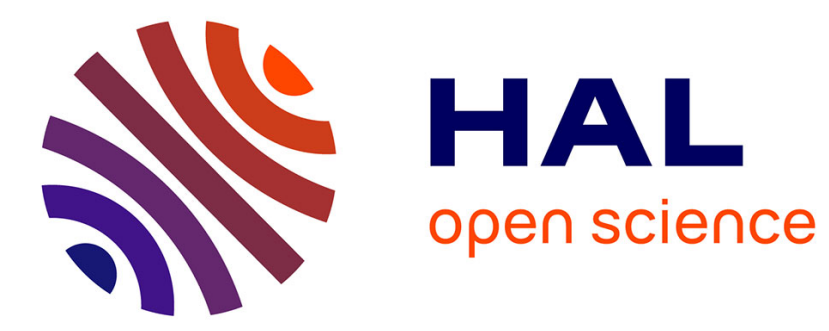

\title{
The preference of adult sheep and goats grazing ryegrass and white clover
}

\author{
Pd Penning, Ja Newman, Aj Parsons, A Harvey, Rj Orr
}

\section{To cite this version:}

Pd Penning, Ja Newman, Aj Parsons, A Harvey, Rj Orr. The preference of adult sheep and goats grazing ryegrass and white clover. Annales de zootechnie, 1995, 44 (Suppl1), pp.113-113. hal-00889277

\section{HAL Id: hal-00889277 \\ https://hal.science/hal-00889277}

Submitted on 1 Jan 1995

HAL is a multi-disciplinary open access archive for the deposit and dissemination of scientific research documents, whether they are published or not. The documents may come from teaching and research institutions in France or abroad, or from public or private research centers.
L'archive ouverte pluridisciplinaire HAL, est destinée au dépôt et à la diffusion de documents scientifiques de niveau recherche, publiés ou non, émanant des établissements d'enseignement et de recherche français ou étrangers, des laboratoires publics ou privés. 


\title{
The preference of adult sheep and goats grazing ryegrass and white clover
}

\author{
PD Penning ', JA Newman 2, AJ Parsons ', A Harvey ', RJ Orr ${ }^{1}$ \\ "IGER, North Wyke, Okehampton, Devon EX2O 2SB UK ; 2Dept of Zoology, Southern Illinois University, \\ Carbondale, IL 62901-6501, USA
}

Sheep and goats have been shown to select different diets when grazing grass/white clover mixtures, with more clover in the diet of sheep (eg Hughes et al, 1984, Proc NZ Soc Anim Prod, 44, 109-112). To measure dietary preference, six groups of three Scottish Halfbred ewes and their twin lambs and six groups of three British Saanen does and their twin kids were tested on twelve $50 \times 50 \mathrm{~m}$ plots containing adjacent blocks of clover monoculture (Trifolium repens L. cv Kent Wild White) and perennial ryegrass monoculture (Lolium perenne L. cv Parcour). There was either $20 \%$ clover : $80 \%$ grass by area $(50 \times 10 \mathrm{~m}$ of clover alongside $50 \times 40 \mathrm{~m}$ grass) or $80 \%$ clover : $20 \%$ grass $(50 \times 40 \mathrm{~m}$ of clover alongside $50 \times 10 \mathrm{~m}$ grass). Prior to the test the sheep and goats grazed, as separate species, for 12 days on plots containing $50 \%$ clover : $50 \%$ grass by area. Each sward was maintained at $6 \mathrm{~cm}$ sward surface height. For the test, groups were released at 10:30 $\mathrm{h}$ onto the dividing line between grass and clover. The experiment had a 2 (sheep and goats) $\times 2$ (20 or $80 \%$ clover by area) factorial design with treatments

$\%$ of grazing time on white clover

Day 1

Goats

$20 \%$ clover

$80 \%$ clover

Mean

Sheep

$20 \%$ clover $80 \%$ clover Mean replicated three times and the preference test ran for $72 \mathrm{~h}$. The position of one focal animal per group was observed using time-lapse video recording (on grass or clover) on each plot and the grazing behaviour (grazing, ruminating or idling) was measured using radio-telemetry and an automatic recording system (Penning et al, 1984, Grass Forage Sci, 39, 345-351).

Sheep tended to spend a higher \% of their grazing time on clover over the three days than did goats $(69.5 \vee 51.8)$, but this was not significant. For those animals offered $20 \%$ clover by area, sheep in particular had a greater preference for clover than was present. Within each of the three days there was a marked diurnal pattern in preference, which was high for clover in the morning and low in the period prior to sunset. The level of preference for sheep measured here is similar to previous results (Parsons et al, 1994, J Anim Ecol, 63, 465-478; Newman et al, 1994, Anim Behav, 47, 185-193). Even goats, which in some circumstances have been shown actively to avoid clover (eg Clark et al, 1982, Proc NZ Soc Anim Prod, 42, 155-157), spent as much time grazing clover as grass. 